\title{
UTILIZATION OF SULFUR SLUDGE RESULTS FROM THE MANUFACTURING OF SULFURIC ACID IN A FILTER AID PRODUCTION
}

\author{
Khalil, M. M. ${ }^{(1)}$; Abdel Razek, T. A. ${ }^{(2)}$; El-Fiki M. A. ${ }^{(3)}$ \\ and Youssef, M. Y.
}

1) Faculty of Science, Ain Shams University 2) Institute of Environmental Studies and Research, Ain Shams University 3) Abu Zaabal for Fertilizer and Chemical Co.

\begin{abstract}
Sulfuric acid manufacture generates huge quantity of sulfur sludge causing major environmental problems in their storage and disposal. On the other hand, molten sulfur should be filtered for sulfuric acid production to remove solids that may plug sulfur spray nozzles or accumulate on catalyst beds that increasing the pressure drop and decreasing operating durations.

In this study, attempts were carried out using sulfur sludge wastes a filler in the manufacturing of filter aid. The filter aid using sulfur sludge is compared with the other filter aids such as Kessel Gohar diatomite (global product) and ABU ZAABLE 12 "AB12" (local product).

Results showed that the prepared filter aid using sulfur sludge as filler decreases the ash content in filtrated sulfur than Kessel Gohar diatomite and AB12 with a ratio of about $26.4 \%$ and $39.4 \%$, respectively, and thus results in increasing the operating durations due to decreasing the amount of ash deposited in the catalyst beds compared with filter aids of Kessel Gohar diatomite and $\mathrm{AB} 12$ with a ratio of about $25.2 \%$ and $39.4 \%$ respectively.

On the other hand, sulfur sludge filter aid also improves filter operating duration than Kessel Gohar diatomite and AB12 with a ratio of about $-1.2 \%$ and $32.4 \%$ respectively. Finally, sulfur sludge filler in manufacturing of filter aid can be used as a reusable material without any change on the ash content in filtrated sulfur and filter operating duration.

Key words: Solid wastes, sulfuric acid, Sulfur sludge, Filter aid, Kessel Gohar, Abu Zaabal 12.
\end{abstract}


J. Environ. Sci.

Institute of Environmental Studies and Research - Ain Shams University

\section{INTRODUCTION}

It is difficult to believe that a very active chemical such as sulfuric acid is at the same time one of the most widely used and most important technical products. It is the agent for sulfate formation and for sulfonation, but more frequently, it is used because it is a rather strong and cheaply priced inorganic acid. It enters into many industries, though infrequently appearing in the finished material. It is employed in the manufacture of fertilizers, leather, and tin plate, in the refining of petroleum, and in the dyeing of fabrics (Ashar and Golwalkar, 2013).

Contact process for sulfuric acid manufacturing depends on elemental sulfur as a raw material, which the rapid melting sulfur tank used a steam tube to be melt. The molten coarse sulfur was over-flowed into the filtration tank and delivered into the molten sulfur filter by a filter pump.

Then filter aid, was added to remove the solid impurities by filtration, and then molten sulfur was injected by the pure sulfur pump into the sulfur combustion furnace respectively by two sulfur lances or more. The sprayed fine particles of liquid sulfur was combusted to form sulfur dioxide in the dry air generating a huge quantity of heat, which recovered by a waste-heat boiler, within conversion section, sulfur dioxide converted to sulfur trioxide with vanadium pent-oxide catalyst occurs in chemical converter containing $4 \sim 5$ beds. After that the sulfur trioxide was absorbed by sulfuric acid with concentration 98 98.5\% in the absorption towers and adjusting concentration by adding water. The conversion and absorption may occur in one stage or 
two stages but two stages are good for the environment and known as Double absorption double catalyst (King et al., 2006).

One of the wastes resulted from the process of sulfuric acid production plant is sulfur sludge results from the filtration of molten sulfur (Beschkov, 2006).

The separation of solids from a suspension in liquid by means of porous medium or screen, which retains the solids and allows the liquid to pass, is termed filtration. The pores of the medium are larger than the particles that are removed, and the filter works efficiently only after an initial deposit has been trapped in the medium. Thus, the main factors that affected on filtration operation are:

a. The properties of the fluid, particularly its viscosity, density and corrosive properties.

b. The nature of solids -its particle size and shape, size distribution and packing characteristics.

c. The concentration of solids in suspension.

d. The quantity of material to be handled and its value.

e. The valuable product is the solid, the fluid, or both (Richardson et al., 2002).

Filter Aids is a group of inert materials that can be used in filtration pretreatment. There are two objectives related to the addition of filter aids. One is to form a layer of second medium which protects the basic medium of the system. This is commonly referred to as "precoat". The second objective of filter aids is to improve the flow rate by decreasing cake compressibility and increasing cake permeability. This type of usage is termed as "admix" or 
"body feed". Filtration without filter aid, with precoat, and with precoat and body feed is shown in Fig. 1 (AFS, 2016).
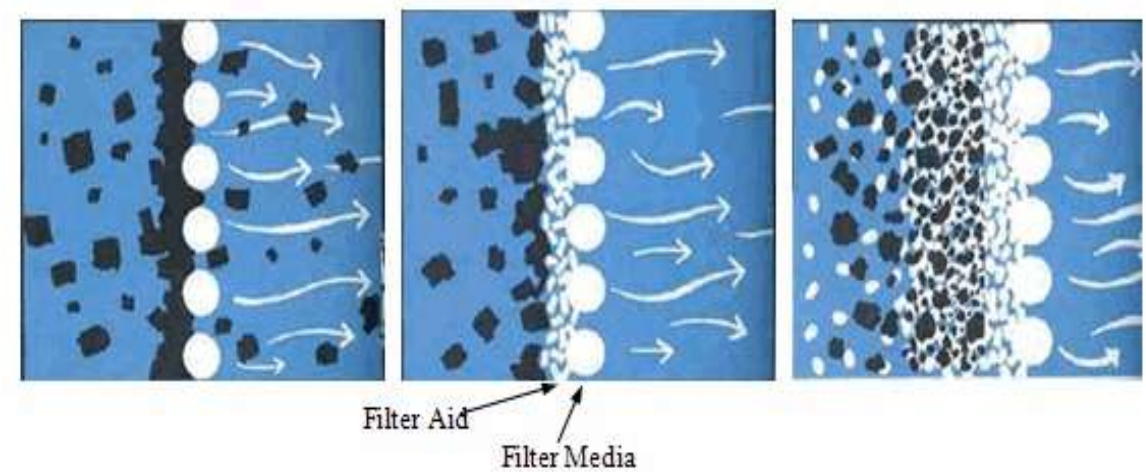

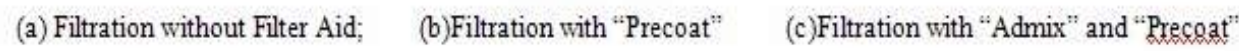

Fig.(1): Mechanism of filtration with filter aid

Filter aids are inorganic mineral powders or organic fibrous materials which are used in combination with filtration hardware to enhance filtration performance. Commonly encountered filter aids include diatomite, perlite and cellulose (Hunt, 1999).

Filter aids are used in conjunction with a variety of filtration equipment to enhance or enable to solid-liquid separations. Typical filtration hardware, in which filter aids might be employed includes:

- Filter Press and Chamber Filters.

- Horizontal and Vertical Leaf Filters.

- Candle or Tubular Filters.

- Rotary Vacuum Precoat Filters.

- Belt Press Filters.

- Lenticular or Cassette Depth Filters. 
Selection depends upon the size of the specific application and the filtration objective (Johnston, 1998).

Filter aid as a precoat is applied in advance of filtration on the septum to protect against the penetration of unwanted solids and premature blinding of the media. Filter aid is also used as a body feed to the liquid being filtered. The solids of filter aid and turbidity continuously build up a cake on the surface of the media until the space between adjacent leaves is filled up or the pressure reaches a maximum (Rees and Cain, 1990).

Filter aid types used in solid-liquid separations include inorganic mineral powders, which comprises processed diatomaceous earth, known as diatomite perlite, a vitreous aluminum silicate of volcanic origin; and organic fibrous materials, such as cellulose and cotton linter. A mineral filter aid of organic origin, introduced in recent years is rice hull ash. Synthetic silicates made from siliceous filter aids can be used as both adsorbents and filter aids. Depth filters themselves contain diatomite, perlite and cellulose, plus resins and strength additives. These products, when used without supplemental filter aids, are suited to low solids applications, as they tend to blind quickly when subjected to moderate-to-high level of solids. Their capacity can be increased by the addition of filter aid, as a precoat and as a body-feed into the unfiltered liquid (Sulpizio, 1999).

Johnston (1999) reported that diatomite, perlite and cellulose are the most widely used porous media (filter aids) in dynamic process filtrations, with a high percentage of fine filtration applications using diatomite. 
Diatomite is obtained from diatomaceous earth, sediment greatly enriched in biogenic silica in the form of the siliceous frustules of diatoms, a diverse array of microscopic, single-cell algae of the class Bacillariophyceae. These frustules are sufficiently durable to retain much of their structure through long periods of geologic time and through thermal processing. Diatomite products are characterized by an inherently intricate and highly porous structure composed primarily of silica, along with impurities of alumina, iron oxide, and alkaline earth oxides (Kumar and Awasthi, 2009).

Perlite is a naturally occurring volcanic glass, which thermally expands upon processing. Perlite is chemically a sodium potassium aluminum silicate. After milling, a porous, complicated structure is present, but because its structure is not as intricate (or tortuous) as that of diatomite, perlite is better suited to the separation of coarse micro particulates from liquids having high solids loading. Cellulose filter media is produced by the sulfite or sulfate processing of hard woods. Cellulose is characterized by its high aspect ratio, which enables it to precoat a septum very easily. It is most often used in that capacity in combination with diatomite. Like perlite, cellulose possesses a less intricate structure than diatomite (Perlmutter, 2015)

This work aims at decreasing the environmental pollution not only by converting some of the industrial wastes (sulfur sludge) which haven't any commercial values and environmentally unacceptable to more available and environmental friendly materials but also sulfur sludge (SS) can be used to produce a new filter aid for sulfur filtration with good and competitive quality. 


\section{MATERIALS AND METHODS}

\section{Materials:}

i. Abu Zaabal 12 (AB12) filter aid was locally prepared in Abu Zaabal Fertilizer and chemical company (AZFC).

ii. Kessel Gohar diatomite filter aid was purchased from china for Xinghui filter aid Company.

iii. Sulfur sludge wastes produced from filtration of molten sulfur.

iv. Aluminum silicate powder was purchased from Modern for Chemical Industries company (MCI).

\section{Methods:-}

Determination of ash content on sulfur:

Weigh molten sulfur sample into a previously ignited, cooled, and weighed, high form porcelain crucible and place on a hot plate. Control the hot plate so that the sulfur burns slowly but completely in fuming compound. After the sulfur has burned off completely, ignite in a muffle furnace at 800 ${ }^{\circ} \mathrm{C}$, cool in a desiccator, and weigh. Repeat the ignition until the weight is constant. One 30-minutes ignition is usually sufficient.

Calculation: Ash \% = residue wt. $\times 100 /$ sample wt.

(According to Sulfur Information Service)

Preparation of sulfur sludge filter aid :

Sulfur Sludge (SS) samples were collected from the industrial facility for sulfuric acid production in Abu-Zaabal for Fertilizers and Chemicals Company (AZFC). The samples were left in atmospheric air for a sufficient period (two weeks) after washing with concentrated sulfuric acid, and then pulverized, homogenized and sieved using different sieves ranged from 
$(0.125 \mathrm{~mm}$ to $0.4 \mathrm{~mm})$, after that add aluminum silicate powder to sulfur sludge powder.

\section{RESULTS AND DISCUSSION}

Characterization of sulfur sludge (SS): The chemical analysis of sulfur sludge material used in this study is summarizedin table1 as shown.

Table (1): The chemical analysis of sulfur sludge material

\begin{tabular}{|c|c|}
\hline Component & $(\% \mathrm{w} / \mathrm{w})$ \\
\hline$S$ & 56 \\
\hline $\mathrm{SiO}_{2}$ & 32.70 \\
\hline $\mathrm{Fe} 2 \mathrm{O} 3$ & 4.00 \\
\hline $\mathrm{Al}_{2} \mathrm{O}_{3}$ & 2.50 \\
\hline$M g O$ & 0.41 \\
\hline $\mathrm{CaO}$ & 0.50 \\
\hline $\mathrm{Na}_{2} \mathrm{O}$ & 0.30 \\
\hline$K_{2} O$ & 0.18 \\
\hline $\mathrm{MnO}$ & 0.03 \\
\hline$F$ & 0.05 \\
\hline Free moisture $\left(\mathrm{H}_{2} \mathrm{O}_{\text {Free }}\right)$ & 2.23 \\
\hline \multicolumn{2}{|c|}{ Trace elements (ppm) } \\
\hline$\overline{C u}$ & 3.00 \\
\hline As & 0.10 \\
\hline$C d$ & 0.1 \\
\hline$N i$ & 2.00 \\
\hline $\mathrm{Zn}$ & 3.00 \\
\hline$P \boldsymbol{P b}$ & 0.15 \\
\hline
\end{tabular}


From this table was found that the main component of sulfur sludge is elemental sulfur beside some oxides such as silica, iron and aluminum oxides and also presence of low concentration of heavy metals in percentages does not exceed the limiting and guidance values .

Effect of sulfur sludge filter aid on the ash content in filtered sulfur

Table (2): Comparison between the ash content in filtered sulfur using different filter aids (PPM)

\begin{tabular}{|c|c|c|c|c|c|c|}
\hline $\begin{array}{c}\text { Typesof } \\
\text { filter aid }\end{array}$ & $\begin{array}{c}\mathbf{1}^{\text {st }} \\
\text { sample }\end{array}$ & $\begin{array}{c}\mathbf{2}^{\text {nd }} \\
\text { sample }\end{array}$ & $\begin{array}{c}\mathbf{3}^{\text {rd }} \\
\text { sample }\end{array}$ & $\begin{array}{c}\mathbf{4}^{\text {th }} \\
\text { sample }\end{array}$ & $\begin{array}{c}\mathbf{5}^{\text {th }} \\
\text { sample }\end{array}$ & Mean \\
\hline \hline S.S filter aid & 9.2 & 8.56 & 8.12 & 8.11 & 7.92 & 8.38 \\
\hline $\begin{array}{c}\text { Diatomite } \\
\text { filter aid }\end{array}$ & 11.8 & 11.8 & 11.4 & 11.1 & 10.82 & 11.38 \\
\hline $\begin{array}{c}\text { Abu Zaabl 12 } \\
\text { filter aid }\end{array}$ & 15.4 & 15.1 & 13.8 & 12.4 & 12.4 & 13.82 \\
\hline
\end{tabular}

From table 2, it is clear that the ash content in filtered sulfur was decreased using sulfur sludge (SS) filter aid less than Kessel Gohar diatomite and $\mathrm{AB} 12$ with a ratio of about $26.4 \%$ and $39.4 \%$ respectively, as shown in fig. (2). 
J. Environ. Sci.

Institute of Environmental Studies and Research - Ain Shams University

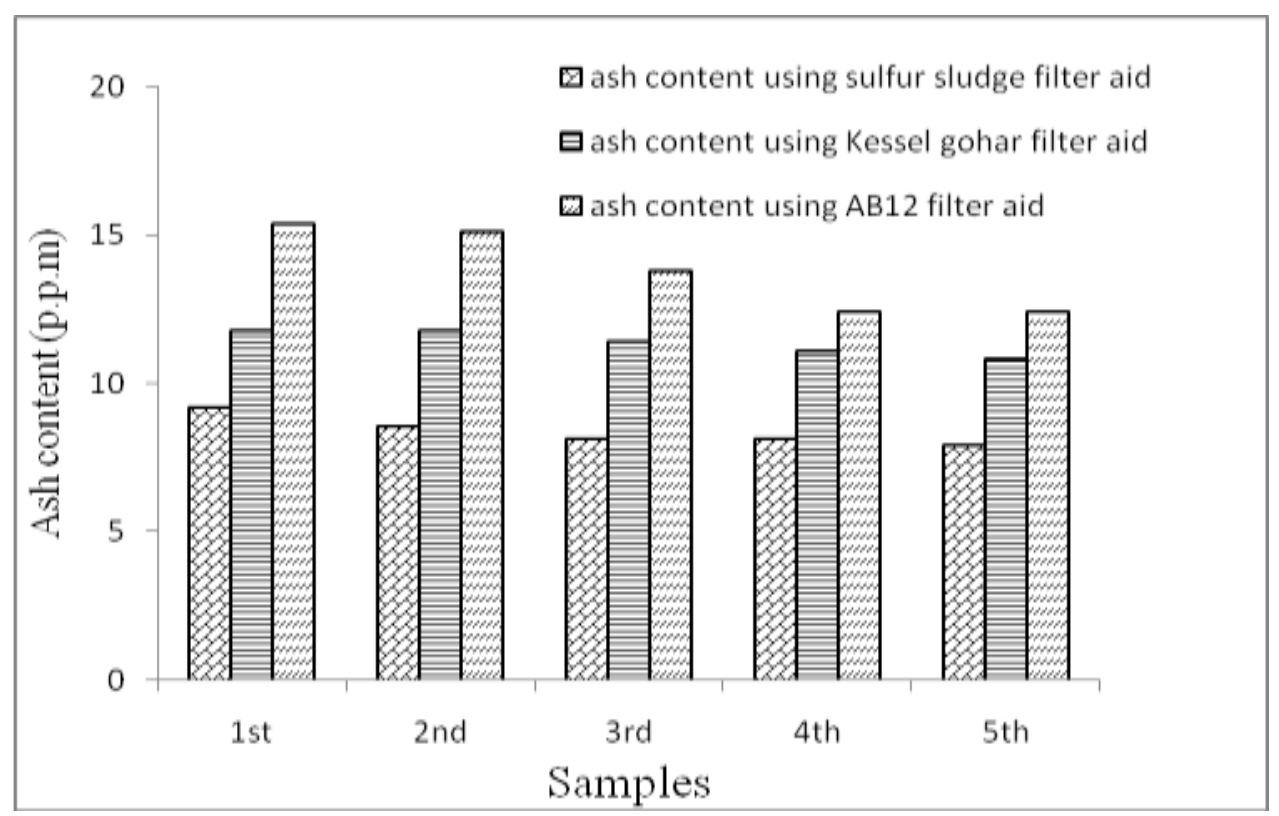

Fig. (2): Effect of using different filter aids on ash content of the molten sulfur filtrate.

From table 1 it is clear that the decreasing ash content of filtered sulfur leads to increasing the operating durations due to decreasing the amount of ash deposited in the catalyst beds and keep the pressure drop in the catalyst beds in the normal standard levels.

As an actual prototype unit of 2000 ton per day (TPD) of sulfuric acid needs 653 TPD of sulfur, the amount of ash deposited in catalyst beds can be calculated using different filter aids as shown in the table 2. 
Table (3): Comparison between three filter aids according to amount of ash in day and year per $(\mathrm{kg})$

\begin{tabular}{|c|c|c|c|}
\hline $\begin{array}{c}\text { Types of filter } \\
\text { aid }\end{array}$ & Ash mean & $\begin{array}{c}\text { Amount of ash } \\
\text { deposited in } \\
\text { converter per day } \\
\text { (kg) }\end{array}$ & $\begin{array}{c}\text { Amount of ash } \\
\text { deposited in } \\
\text { converter per year } \\
\text { (kg) }\end{array}$ \\
\hline Sulfur Suldge & 8.38 & 5.4721 & 1997 \\
\hline Kessel Gohar & 11.38 & 7.3114 & 2669 \\
\hline Abu Zaabl 12 & 13.82 & 9.0245 & 3294 \\
\hline
\end{tabular}

From table 3 it is clear that decreasing ash content of filtered sulfur that using sulfur sludge (SS) filter aid lead to increase of the operating durations due to decrease the amount of ash deposited in the catalyst beds compared to filter aids of Kessel Gohar diatomite and $\mathrm{AB} 12$ with a ratio of about $25.2 \%$ and $39.4 \%$ respectively, as shown in fig. 3.

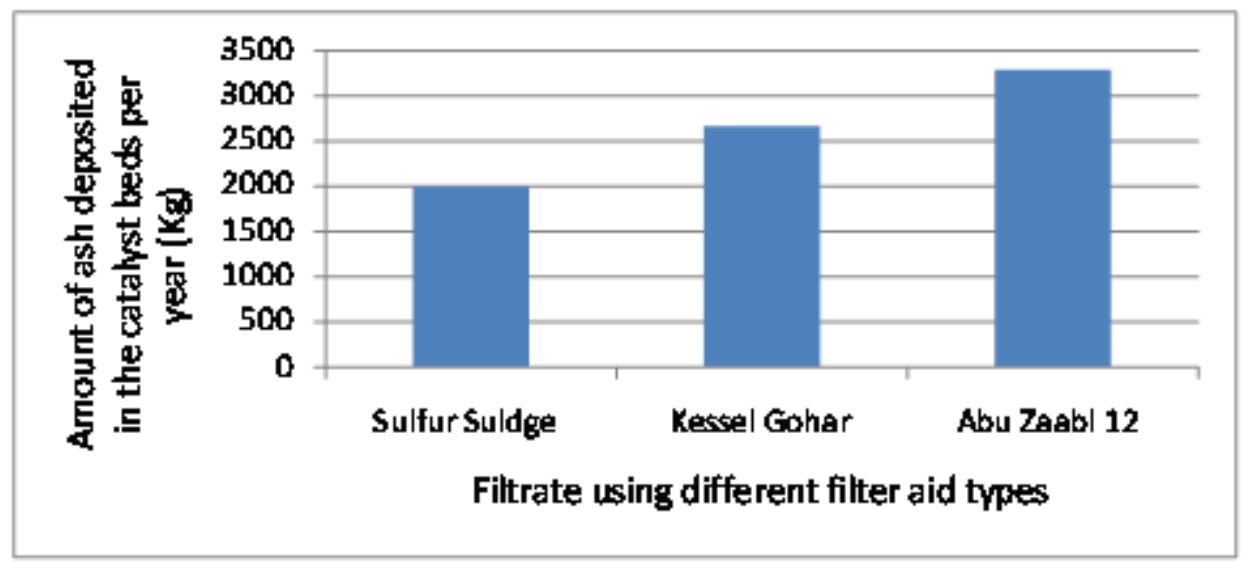

Fig. (3): Amount of ash content deposited in the catalyst beds per years with using different filter aid in the filtration of molten sulfur.

Effect of sulfur sludge filter aid on rate of filtration and comparing it with different filter aid 
J. Environ. Sci.

Institute of Environmental Studies and Research - Ain Shams University

Table (4): Comparison between the required time needed to filter 500 tons of molten sulfur using different filter aids.

\begin{tabular}{|c|c|c|c|}
\hline Samples & $\begin{array}{c}\text { S.S filter } \\
\text { aid }\end{array}$ & $\begin{array}{c}\text { Kessel Gohar } \\
\text { filter aid }\end{array}$ & AB12 filter aid \\
\hline \hline $1^{\text {st }}$ & 9 & 8.30 & 13 \\
\hline $2^{\text {nd }}$ & 8.35 & 8.35 & 12.45 \\
\hline $3^{\text {rd }}$ & 8.30 & 8.30 & 13 \\
\hline $4^{\text {th }}$ & 8.45 & 8.45 & 12.5 \\
\hline $5^{\text {th }}$ & 8.40 & 8.40 & 12.45 \\
\hline Mean & 8.45 & 8.35 & 12.5 \\
\hline
\end{tabular}

Sulfur sludge filter aid also improves the rate of filtration compared with Kessel Gohar diatomite and better than $\mathrm{AB} 12$ with a ratio of about $-1.2 \%$ and $32.4 \%$, respectively, as shown in fig. 4 , this may be due to the highly porous structure.

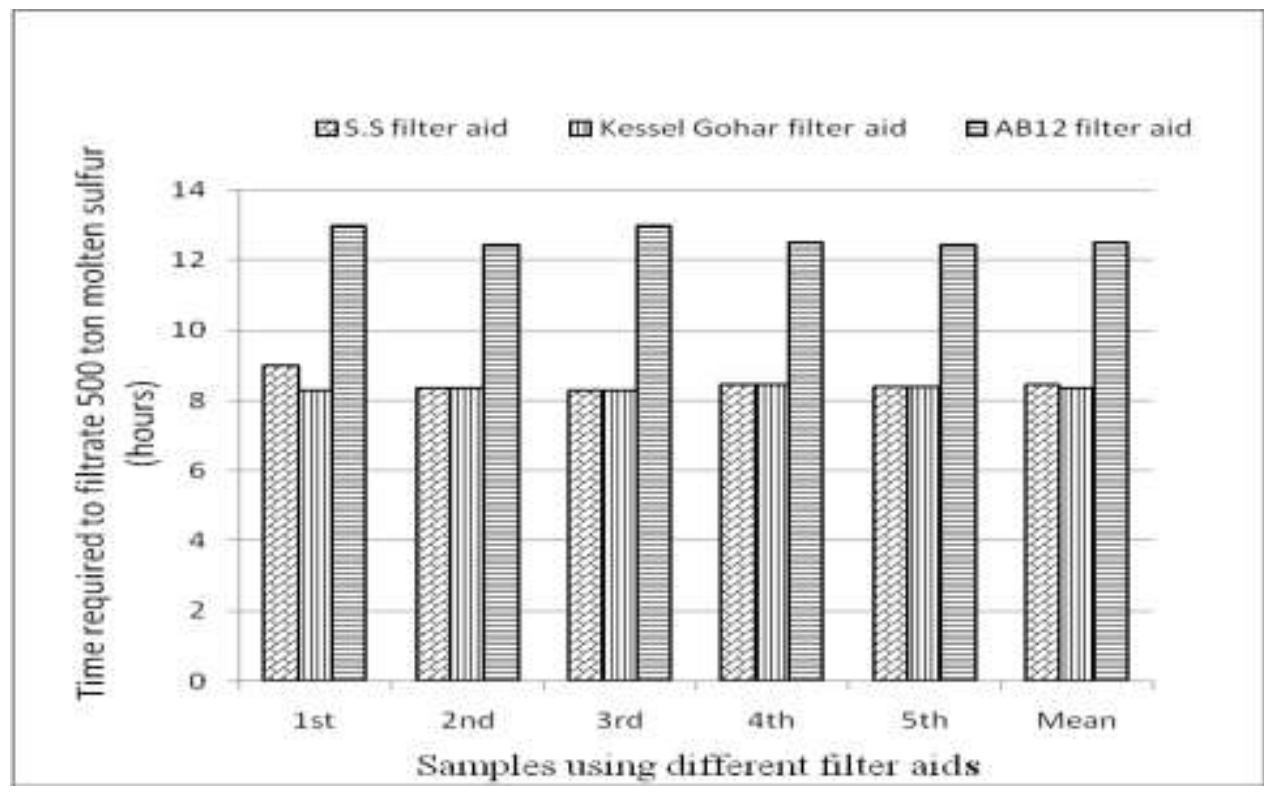

Fig. (4): Effect of different filter aid on rate of filtration 
Effect of sulfur sludge filter aid on rate of filtration and comparing it with different filter aid

Sulfur sludge filler in manufacturing of filter aid can be used as a reusable material without any change on the ashes in filtered sulfur and filter operating duration as shown in fig. 5.

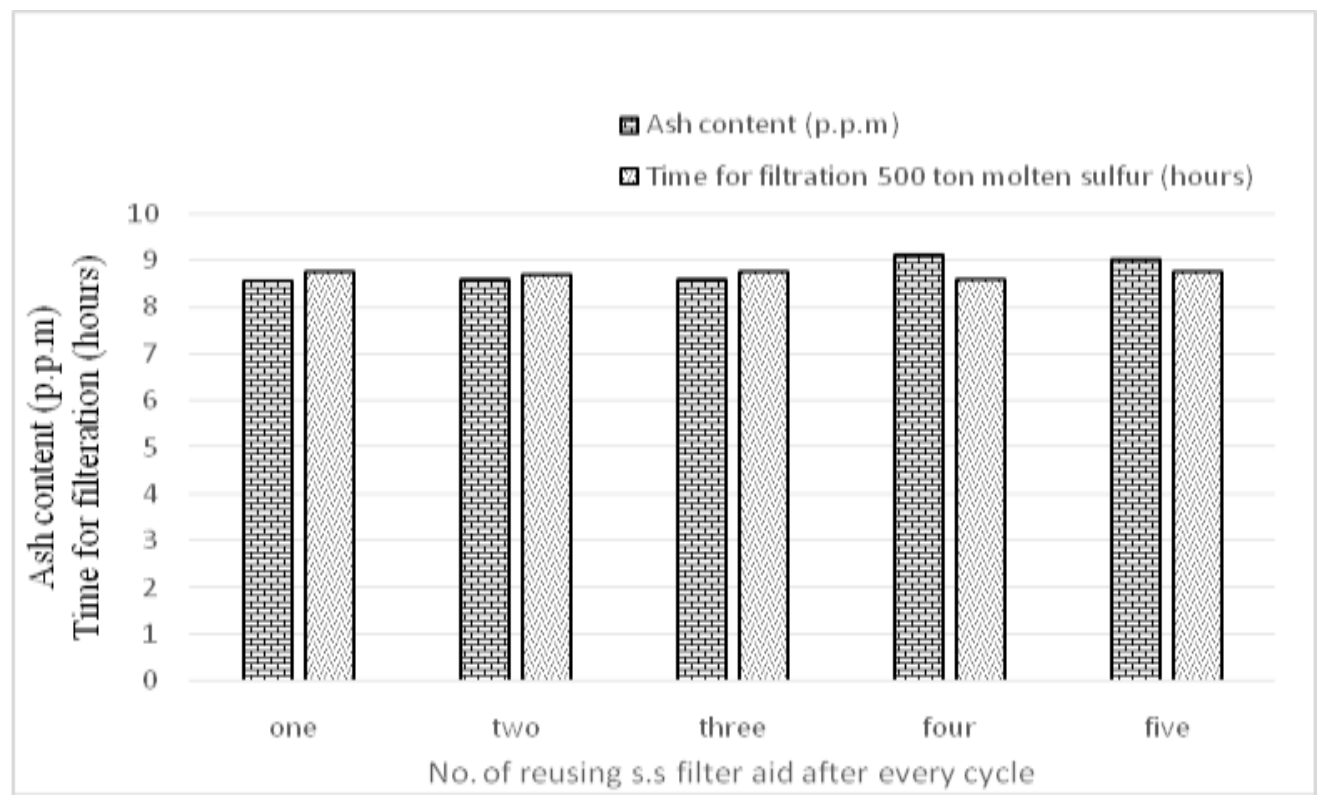

Fig.(5): Effect of reusing sulfur sludge produced after every cycle in the manufacture of S.S filter aid.

\section{CONCLUSION}

The prepared sulfur sludge filter aid decreases the ash content infiltrated sulfur than Kessel Gohar diatomite and AB12, this lead to increasing the operating durations due to decreasing the amount of ashes deposited in the catalyst beds. 
Sulfur sludge filter aid also improves the rate of filtration as Kessel Gohar diatomite and better than AB12.

Sulfur sludge filter aid can be used as a reusable material (used for many times) without any change in the ashes content infiltrated sulfur and rate of filtration.

\section{REFERENCES}

(AFS) American Filtration and Separations society (2016): What are filter aids?, [online] available: seen in (march2017)

https://www.afssociety.org/what-are-filter-aids/

Ashar, N. G. \& Golwalkar, K. (2013): "A Practical Guide to the Manufacture of Sulfuric Acid, Oleums, and Sulfonating Agents", Springer, Germany.

Beschkov, V. (2006): "pollution control in industrial process, vol. 3, encyclopedia of life support systems (EOLSS)". Developed under the Auspices of UNESCO, EOLSS, Paris.

Kumar, A. \& Awasthi, A. (2009): Bioseparation engineering, P.41, I. K International publishing house pvt, Ltd.

Hunt, T. (1999): "Filter Aids," Encyclopedia of Bioprocess Technology, Flickinger, New York.

Johnston, P. R. (1998): Filtration \& Separation, Vol. 35, No. 3, p. 287-292, Elsevier, USA, Available online 15 December 2003.

https://doi.org/10.1016/S0015-1882 (98)90341-X

Johnston, P. R. (1999): “About Pore-Size Distribution,” Filtration News, Vol. 17, No.1, pp. 42-45, Elsevier, USA.

King, M. J. (2006): "Sulfuric Acid Manufacture analysis control and optimization", Elsevier, USA.

Louie, D. K. (2005): "Handbook of Sulfuric Acid Manufacturing" Canada, 51, 5-58, DKL Engineering, Inc. 
Perlmutter, B. A. (2015): "Solid-liquid filtration practical guides in chemical engineering" Ch.1, P.8-12, Elsevier.

Rees, R. H. \& Cain, C. W. (1990): "Let Diatomite Enhance Your Filtration" Chemical Engineering, 97, (8), August, pp. 72-74.

Richardson, J. F.; Backhurst, J. R. \& Harker, J. H. (2002): "Coulson and Richardson's chemical engineering Particle Technology and Separation Process"Butterworth-Heinemann, 2, 5th ed., pp.208269, Oxford.

Sulpizio, T. E. (1999): Advances in filter aid and precoat filtration technology, Presentation at the American Filtration \& Separations Society, Annual Technical Conference, Boston, Massachusetts.

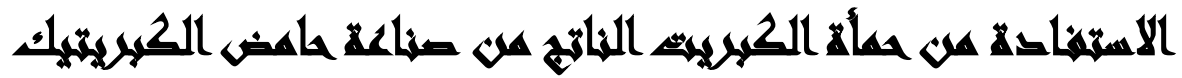

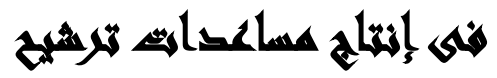

$[r]$

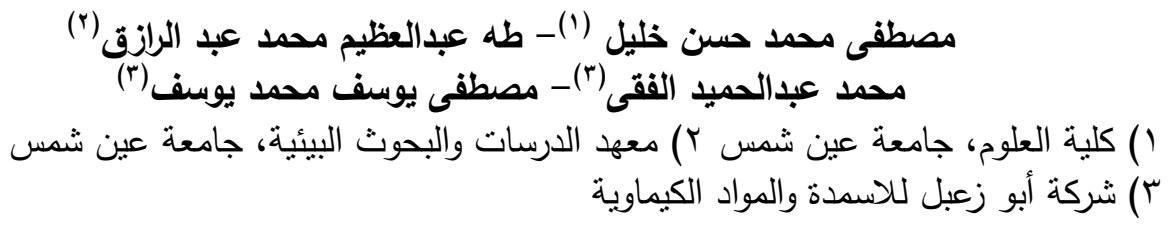

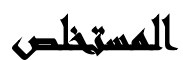

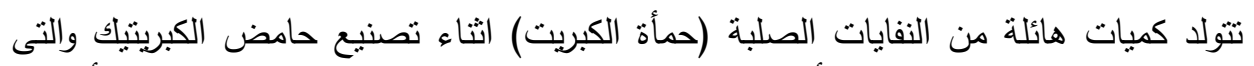

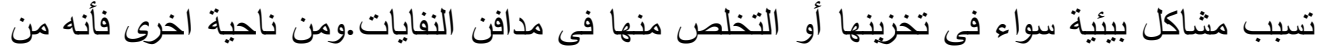

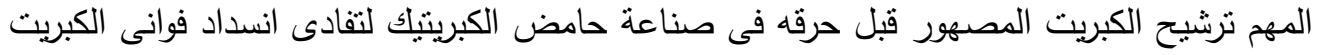

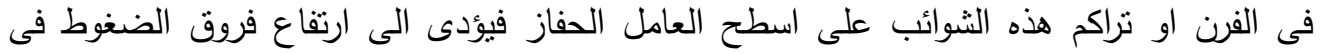

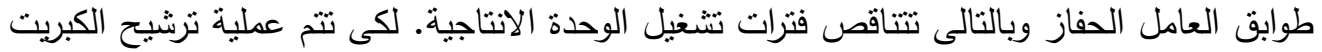

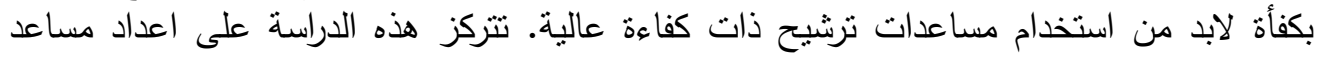

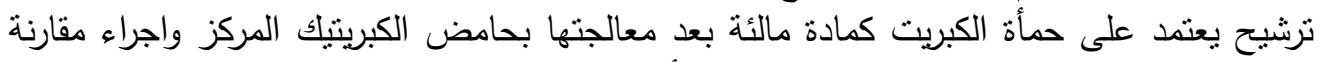

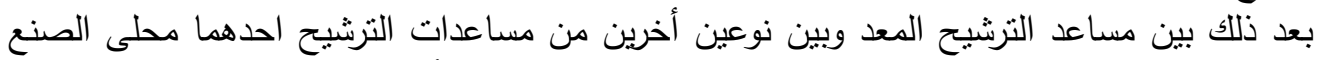

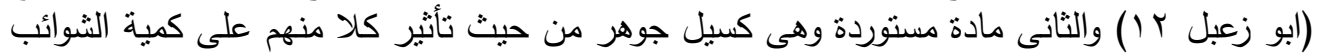
الموجودة بالكبريت المصهور المرشح عن طريق كلا منهم كذلك المعدل الزمنى للترشيح. أظهرت 


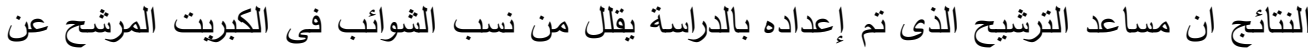

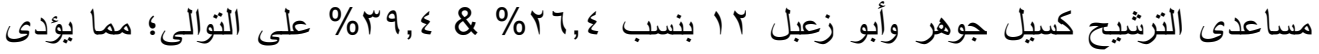

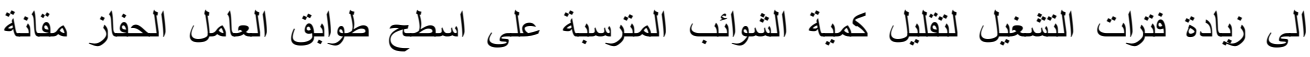

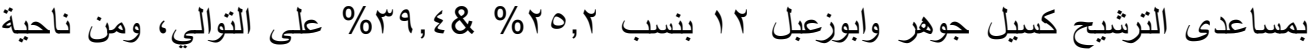

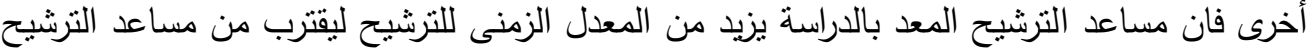

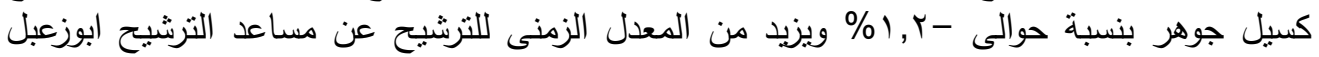

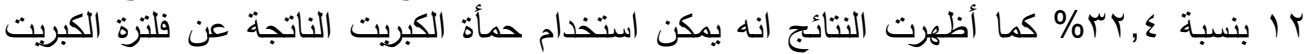

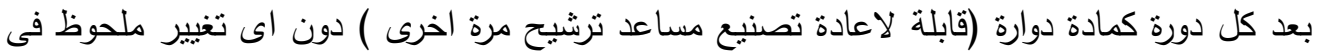

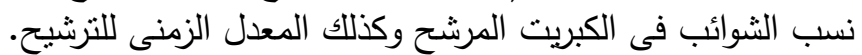

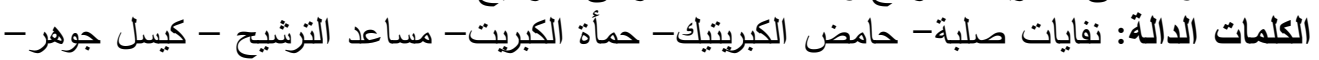

